\title{
What Is Beneficial Use of Water?
}

U NDER the law of prior appropriation of water the prior appropriator is entitled to retain from later claimants the water which he puts to beneficial use. Beneficial use is now the final test. ${ }^{1}$

What is beneficial use? In collecting the authorities four years ago, the present writer said: "The question is one of fact, a very general one, to be left broadly to the jury (or to the court, if sitting without one), and the result in any particular case will depend upon the attitude which the jury (or judge), as reasonable men, will take toward the evidence as a whole when presented to them at the trial." ${ }^{2}$ It is the object of this paper to consider the decisions since rendered.

1 "An inherent and necessary limitation." Schodde v. Twin Falls L. \& W. Co. (Idaho, 1911), 224 U. S. 107, 53 I. Ed. 686, 32 Sup. Ct. Rep. 470. "Not as new legislation, but as the established definition of a water right." San Joaquin etc. Canal \& Irr. Co. v. Stanislaus County, (Cal., 1911), 191 Fed. 875, 896; Imperial Water Co. v. Holabird (Cal., 1912), 197 Fed. 4, quoting the Desert Land Act of March 3, 1877, 19 Stat. 377, and saying that this is applicable to irrigation on all public lands.

California: Evans Ditch Co. v. Lakeside Ditch Co. (1910), 13 Cal. App. 119, 108 Pac. 1027; Hufford v. Dye (1912), 162 Cal. 147, 121 Pac. 400; Dannenbrink v. Burger (1913), 23 Cal. App. 587, 138 Pac. 751; In re James A. Murray (1913), 2 Cal. Ry. Com. Dec. 464; 1913 Stat. Cal. 1012, §\& 11, 20; Cal. Civ. Code, § 1411.

Idaho: Lee v. Hanford (1912), 21 Idaho, 327, 121 Pac. 558; Bennett v. Nourse (1912), 22 Idaho, 249, 125 Pac. 1038; Washington State Sugar Co. v. Goodrich (Idaho, Mar. 3, 1915), 147 Pac. 1073.

Oregon: Caviness v. La Grande Irr. Co. (1911), 60 Ore. 410, 119 Pac. 731; Cantrall v. Sterling Mining Co. (1912), 61 Ore. 516, 122 Pac. 42; Little Walla Irr. Union v. Finis Irr. Co. (1912), 62 Ore. 348, 124 Pac. 666, 125 Pac. 270; Claypool v. O'Neill (1913), 65 Ore. 511, 133 Pac. 349.

Wyoming: Nichols v. Hufford (Wyo., 1913), 133 Pac. 1084.

2 Wiel, Water Rights in the Western States, 3d ed. $\$ 481$. 
I.

Negatively, the recent decisions upon "beneficial use" have been strong; that is, in laying down what it is not. It is not the amount originally claimed in a notice of appropriation, or in an application to the state engineer for a permit, or in a permit issued by him. ${ }^{3}$ It is not the capacity of the appropriator's ditch when a reasonable time has elapsed without diverting that amount of water into it. ${ }^{4}$ It is also not even the quantity of water actually diverted into the ditch, however long such diversion was continued ${ }^{5}$ and it is not what is used at time of largest use alone, but varies with use at other times, ceasing entirely at such parts of the season as the use ceases. ${ }^{8}$

These negative propositions repeat in recent decisions. Partly this is because the older claimants (slow in getting used to them) still press for the contrary; partly because the older decisions to some extent themselves contained matter to the contrary. The pioneers' law of prior appropriation was a possessory law, and

${ }^{3}$ Hufford v. Dye (1912), 162 Cal. 147, 121 Pac. 400, (2000 inches claimed in notice cut down to use); Trimble v. Hellar (1913), 23 Cal. App. 436, 138 Pac: 376; Cal. Pastoral etc. Co. v. Madera Canal etc. Co. (1914), 167 Cal. 78, 138 Pac. 718; Washington State Sugar Co. v. Goodrich (Idaho, Mar. 3, 1915), 147 Pac. 1073, (sale passes only the amount beneficially in use by vendor); Bailey v. Tintinger (1912), 45 Mont. 154, 122 Pac. 575; Hedges v. Riddle (1912), 63 Ore. 257, 127 Pac. 548, (amount named in permit); Bowen v. Spaulding (1912), 63 Ore. 392, 128 Pac. 37; Nichols v. Hufford (Wyo., 1913), 133 Pac. 1084. Cf. In re Commonwealth Power Co. (1913), 94 Neb. 613, 143 N. W. 937; Kersenbrock v. Boyes (1914), 95 Neb. 407, 145 N.'W. 837; Hagerman Irr. Co. v. McMurry (1911), 16 N. Mex. 172, 113 Pac. 823; Water Rights in the Western States, 3d ed. $\$ \$ 376,417,473-479$.

4 Peterson v. Cody (1910), 14 Cal. App. 502, 112 Pac. 558; Trimble v. Heller (1913), 23 Cal. App. 436, 138 Pac. 376; Cal. Pastoral etc. Co. v. Madera Canal etc. Co. (1914), 167 Cal. 78, 138 Pac. 718; Dannenbrink v. Burger (1913), 23 Cal. App. 587, 138 Pac. 751; Turner v. East Side Canal etc. Co. (Cal., Mar. 23, 1915), 147 Pac. 579; Bailey v. Tintinger (1912), 45 Mont. 154, 122 Pac. 575, (after a reasonable time); Conrow v. Huffine (1914), 48 Mont. 437, 138 Pac. 1094; Nichols v. Hufford (Wyo., 1913), 133 Pac. 1084.

5 Hufford v. Dye (1912), 162 Cal. 147, 121 Pac. 400; Cal. Pastoral etc. Co. v. Madera Canal etc. Co. (1914), 167 Cal. 78, 138 Pac. 718; Dannenbrink v. Burger (1913), 23 Cal. App. 587, 138 Pac. 751; San Joaquin etc. Canal \& Irr. Co. v. Stanislaus County (Cal., 1911), 191 Fed. 875; Little Walla Irr. Union v. Finis Irr. Co. (1912), 62 Ore. 348, 124 Pac. 666, 125 Pac. 270.

- Hufford v. Dye (1912), 162 Cal. 147, 121 Pac. 400; Wolff v. Pomponia (1911), 52 Colo. 109, 120 Pac. 142; Caviness v. La Grande Irr. Co. (1911), 60 Ore. 410, 119 Pac. 731; Sherred v. City of Baker (1912), 63 Ore. 28, 125 Pac. 826; Claypool v. O'Neill (1913), 65 Ore. 511, 133 Pac. 349; In re North Powder River (Ore., 1914), 144 Pac. 485; Parshall v. Cowper (Wyo., 1914), 143 Pac. 302. 
looked upon each as the owner of all he took into possession or "located," which was what his notice said or at least what his ditch held, like a notice or staking-out of a mining location; possession rather than use was the determinative factor." The gradual change since then to a "use" system from a "possessory" one puts upon the decisions now the necessity of disposing of much of what there was in the older law. Thus the Supreme Court of Oregon recently expressly overrules an earlier decision based upon capacity of ditch. ${ }^{8}$ Hence the importance paid by the decisions now to laying down what beneficial use is not.

\section{II.}

Upon the affirmative side, saying what beneficial use is, the inquiry has been devoted. to the "duty of water," whereby "beneficial use" is expressed in scientific units, namely, the water needed per acre of land or the acres irrigable by a unit of water. To the amount of water thereby indicated an allowance is added to cover the necessities of transmission to the land from the source of supply, and the total (consisting of the acreage multiplied by the peracre duty and increased by the transmission allowance) is measured to the appropriator, or is declared to be his right, at the point of diversion from the natural stream, ${ }^{9}$ since it is the flow of the stream as a natural resource that is the basis of any independent water-right.

Before speaking of the "duty of water," the question of transmission allowance may receive a word or two.

The transmission allowance is declared in terms containing some qualification to denote that it must not be excessive; the word "reasonable" being considerably used. Thus, one case in Nevada says transmission losses (seepage and evaporation) are allowed if "reasonable and economical methods of diversion" are shown, ${ }^{10}$ and another in California, if such losses could not be prevented by "reasonable care or precaution,"

T See Water Rights in the Western States, 3d ed. $\S 139$.

8 Donnelly v. Cuhna (1911), 61 Ore. 72, 119 Pac. 331, 332, overruling Coventon v. Seufert (1893), 23 Ore. 548, 32 Pac. 508.

9 Iittle Walla Irr. Union v. Finis Irr. Co. (1912), 62 Ore. 348, 124

Pac. 666. 125 Pac. 270; Bennett v. Nourse (1912), 22 Idaho, 249, 125 Pac. 1038.

10 Doherty v. Pratt (1912), 34 Nev. 343, 124 Pac. 574; but holding a loss of 2-3 volume in 3 miles not such.

11 "Some loss in this way is inevitable and it must be considered a part of that which is necessary to be taken to supply the actual use proposed. There was evidence to the effect that there would be no 
gon says "reasonable care and diligence."12 In another in California it is said such losses are allowed so far as they are "unavoidable."13 In other cases qualifying words are used. ${ }^{14}$ That some allowance will be made is accepted; and in determining how much, examination is made by the court of the facts of each case, and the courts then pass upon whether the degree of loss is shown to be reasonable. ${ }^{15}$

A somewhat analogous allowance has been recognized for affording a head to carry the water to the land and to enable the spread of it when there delivered. The nearer level the grade of ditch between stream and farm, the more water required to maintain a flow in it; the nearer level the irrigated land, the more water required to make water spread when brought there. Some additional allowance to maintain a "head" to meet this has been recognized. ${ }^{16}$ There is no fixed degree laid down to which such allowance will go. These cases leave it discretionary with the court; that is, a "reasonable" allowance upon the facts of each case is made for the purpose.

It appears, therefore, that the degree of transmission allowance being recognized by the courts is such as is reasonable in each

loss of this character which could be prevented by reasonable care or precaution." San Joaquin etc. Co. v. Stevinson (1912), $164 \mathrm{Cal}$. 221, 128 Pac. 924. at 467

12 Joseph Milling Co. v. City of Joseph (Ore., 1914), 144 Pac. 465

13 "There is generally some unavoidable waste in any large irrigation system. Water must be turned into canals leading to lands where it is to be used. The users may not be ready to commence taking it. As it cannot then be turned back and made to run up hill, it must be allowed to run down and go to waste, unless some independent user takes it below the waste gate. So much of the water as may be unavoidably wasted is to be deemed a part of that which is appropriated to the beneficial use and which the company has the right to take. It is necessary to the user and is in the same category, as that lost in transmission by evaporation and unavoidable seepage." Thayer v. California Development Co. (1912), 164 Cal. 117, 128 Pac. 21.

14 Bennett v. Nourse (1912), 22 Idaho, 249, 125 Pac. 1038; Little Walla etc. Union v. Finis Irr. Co. (1912), 62 Ore. 248, 124 Pac. 666, 125 Pac. 270.

15 Incidentally, scientific investigation has shown that evaporation in transmission is a negligible quantity, and large losses are due almost wholly to leakage and seepage. Bulletin $126 \mathrm{U}$. S. Dept. of Agriculture; Bulletin 248 Office Experiment Station, U. S. Dept. of Agriculture; Second Progress Report of Co-operative Irrigation; Investigation in California, by Frank Adams, U. S. Experiment Station Circular 108; State v. Twin Falls Canal Co. (1911), 21 Idaho, 410, 121 Pac. 1039; Little Walla Irr. Union v. Finis Irr. Co. (1912), 62 Ore. 348, 124 Pac. 666.

${ }_{16}$ State v. Twin Falls Canal Co. (1911), 21 Idaho, 410, 121 Pac. 1039; Hedges v. Riddle (Ore., Feb. 9, 1915), 146 Pac. 99; Report of 1908-1910 of State Engineer of Nebraska. 
case upon its own facts, which is a discretionary matter with the court, as are all matters where "reasonableness" governs the decision.

With these transmission factors allowed, the decisions have considered the "duty of water" after it has been delivered to the place of use.

\section{III.}

The duty of water is found not to be a constant factor for all places, but varies with the character of soil and sub-soil, climatic conditions, diversification of farm crops, rotation in use, preparation of land; kind of crop, ${ }^{17}$ ground water level, method of irrigation (whether in deep furrows or by flooding) and various other conditions. ${ }^{18}$ It will also, as already noted, vary with the head under which the water flows. ${ }^{19}$ Consequently the Supreme Court of Oregon says: "We recognize the great difficulty of estab-

17 Alfalfa, for example, needs $50 \%$ more than hay. Report of Idaho State Engineer, 1909-1910, p. 270.

18 "It depends upon the character of the soil, the climate and other conditions, as well as the manner of its application." Little Walla Irr. Co. v. Finis Irr. Co. (1912), 62 Ore. 348, 124 Pac. 666, 125 Pac. 270. In another case it is said: "The duty of water depends upon the character and conditions of the soil," and "The nature of the soil is so varied that it is absolutely impossible to establish a uniform standard of duty of water." Washington State Sugar Co. v. Goodrich (Idaho, Mar. 3, 1915), 147 Pac. 1073. See Report of Idaho State Engineer, 1909-1910, p. 222.

${ }_{10}$ The Supreme Court of Oregon says: "Only a small part of $1 / 2$ inch per acre could be carried to the land without the use of an expensive means of conveying it, which is not justified in this case." Hedges v. Riddle, (Ore., Feb. 9, 1915), 146 Pac. 99. The Supreme Court of Idaho says in State v. Twin Falls Canal Co. (1911), 21 Idaho, 410, 121 Pac. 1039: "It is a well recognized fact that, in order to properly irrigate land, the irrigator must have a proper stream or head of water, and the question arises as to how much water is necessary to furnish a sufficient head or stream for that purpose. I think it will not be disputed that an inch to the acre, if measured out in a constantly flowing stream, is not sufficient for the proper irrigation of a small tract; so for the proper irrigation of small tracts of land there is needed a head or stream of water of sufficient size to be efficiently handled and flowed over the land. It is more convenient and economical to use water in as large heads or volumes as can be conveniently used by the irrigator. Much of the land in the Snake River valley is of the character or kind that, unless you have a sufficient head of water to rush it over the land, the sandy and gravelly soil will absorb all of it and not permit it to pass on over the land. Hence to successfully irrigate land, a sufficient head of water is required to flow entirely over the land. A second-foot of water, which consists of about 50 miner's inches, is as small a stream or head of water as can be efficiently used in the irrigation of the lands in the Snake River valley." State v. Twin Falls Canal Co. (1911), 21 Idaho, 410, 121 Pac. 1039. The State Engineer of Nebraska says in his 
lishing the duty of water,"20 and the Supreme Court of Idaho said: "It is absolutely impossible to establish a uniform standard of duty of water."21

The ruling is that the duty of water is a matter of proof separately in each case according to the facts put in evidence. An Oregon case gives special consideration to this question. A previous Oregon case had been interpreted as fixing a presumption of law for a certain duty of water ${ }^{22}$ and the propriety of the author's interpretation was argued with some heat in the subsequent case. The court settles that there is no presumption in the matter..$^{23}$

The highest duty mentioned in recent decisions that the writer has noted is one-tenth of a miner's inch (I-400 second-foot) per acre $;{ }^{24}$ the lowest, three inches per acre under the conditions shown (gravelly soil and level land). ${ }^{25}$ The proof generally is for a duty of one inch per acre, and awards upon that basis have been made more frequently in the courts of last resort than upon any other. It has been allowed in Colorado, Idaho, Montana, Oregon and

report for 1908-1910: "Where small acres are irrigated under an allotment of 1-70 of one cubic foot per second continuous flow for one acre, the amount allowed is so small that a proper distribution and application is impossible."

20 In re Willow Creek (Ore., 1914), 144 Pac. 505.

21 Washington State Sugar Co. v. Goodrich (Idaho, Mar. 3, 1915), 147 Pac. 1073.

"It is evident that the reasonable degree of perfection of each of these requirements will vary with the locality and with different changing conditions in each locality, so that the beneficial use of water is a variable." Resolution 68 of Conference of Irrigation Managers of U. S. Reclamation Service, quoted in 2 Cal. Law Rev. 373.

22 Water Rights in the Western States, 2 d ed. $\$ 170,3 \mathrm{~d}$ ed. $\$ 481$.

${ }^{23}$ Little Walla Irr. Union v. Finis Irr. Co. (1912), 62 Ore. 348, 124 Pac. 666, 125 Pac. 270, saying: "Neither the law nor the decisions of the courts have fixed a definite or uniform amount as constituting the duty of water for irrigation in all cases, but it depends upon the character of the soil, the climate, and other conditions, as well as the manner of its application." Judge Will $R$. King (formerly of the Oregon Supreme Court, and now chief counsel for the United States Reclamation Service), who had written the opinion in which the alleged presumption was supposed to be contained, said as counsel in a later case: "We have not claimed, nor do we claim now that the courts have a right arbitrarily to fix the quantity of the flow of water required in the irrigation of any certain tract of land. Courts, of course, must be guided by the evidence, and that is all we ask in this case. When we say evidence, we mean sworn testimony, or such as the court will, under the law, be entitled to take judicial cognizance of, and not mere rumors or statements of counsel."

${ }_{24}$ Smith v. Cucamonga W. Co. (1911), 160 Cal. 611, 615, 117 Pac. 764. This specification was contained in an agreement between the parties, and not as a specification of fact by the court.

25 Joyce v. Rubin (1913), 23 Idaho, 296, 130 Pac. 793. 
Washington, subject to modification by evidence in each case. ${ }^{26}$ For example: "While we have no legislation on the subject, the rule has generally been observed by the courts in this state, in fixing the amount required for economical use, to allow one inch per acre, unless the evidence discloses that a greater or less amount is required." 27

This is more than allowed where statutes have enacted a duty of water. An inch per acre is forty to fifty acres per second foot (depending upon whether "inches" are under a six or four inch pressure respectively). The statutes vary from fifty to one hundred acres per second foot. ${ }^{28}$ Where there is such statutory specification, the amount so specified will be followed in the absence or insufficiency of proof of the actual duty of water in the case. ${ }^{29}$ Where, however, proof is offered for a larger amount of water than the statutory duty, it is an open question how far the proof may be heard in such jurisdictions. In Wyoming the court intimated obiter that proof "reasonably clear and satisfactory" might entitle an appropriator to an allotment exceeding the statutory limit, ${ }^{30}$ and in Idaho, the Supreme Court has allowed more than the statutory limit, upon the proof in some cases, ${ }^{31}$ saying that the

${ }^{26}$ Colorado: Larimer County Canal Co. v. Poudre Valley Reservoir Co. (1912), 23 Colo. App. 249, 129 Pac. 248, (sometimes 1-40 second foot).

Idaho: Gerber v. Nampa etc. Irr. Dist. (1908), 16 Idaho, 1, 100 Pac. 80; State v. Twin Falls Canal Co. (1911), 21 Idaho, 410, 121 Pac. 1039, (1 inch). See also Joyce v. Rubin (1913), 23 Idaho, 296, 130 Pac. 793. Montana: Conrow v. Huffine (1914), 48 Mont. 437, 138 Pac. 1094 (1 inch).

Oregon: Gardner v. Wright (1907), 49 Ore. 609, 91 Pac. 286, (1 inch); Hough v. Porter (1909), 51 Ore. 318, 98 Pac. 1083, (1 inch); Whited v. Cavin (1909), 55 Ore. 98, 105 Pac. 396, (1 inch); Ison v. Sturgill (1910), 57 Ore. 109, 109 Pac. 579, (1 inch); Porter v. Pettengill (1910), 57 Ore. 247, 110 Pac. 393, (1 inch); Nevada Ditch Co. v. Canyon etc. Ditch Co. (1911), 58 Ore. 517, 114 Pac. 86, (1 inch); In re Willow Creek (Ore., 1914), 144 Pac. 505, (until May 1, 1-40 second. feet); In re North Powder River (Ore., 1914), 144 Pac. 486 (1 inch). See also Hedges v. Riddle (Ore., Feb. 9, 1915), 146 Pac. 99.

Washington: Sander v. Bull (1913), 76 Wash. 1, 135 Pac. 489, (1 inch).

Federal: United States v. Conrad Inv. Co. (Mont., 1907), 156 Fed. 123 (1 inch); Rodgers v. Pitt (Nev., 1904), 129 Fed. 932, (1 inch).

${ }_{2 i}$ Conrow v. Huffine (1914), 48 Mont. 437, 138 Pac. 1094.

28 Water Rights in the Western States, 3 ed. $\$ 487 ; 1913$ Stat. Nev. ch. $130, \& 11$.

29 Nichols v. Hufford (Wyo., 1913), 133 Pac. 1084.

${ }^{30}$ Nichols v. Hufford ( supra).

31 Gerber v. Nampa etc. Irr. Dist. (1909), 16 Idaho, 1, 100 Pac. 80; State v. Twin Falls Co. (1911), 21 Idaho, 410, 121 Pac. 1039; Joyce v. Rubin (1913), 23 Idaho, 296, 130 Pac. 793. 
varying factors are so many that a uniform standard is impossible, and it depends upon what is reasonable in each case. ${ }^{32}$. In Oregon, where there is a rule adopted by the State Water Board, though no statute, the rule of the board is held not conclusive. ${ }^{33}$ How far a distinction will be made between uses begun before and after the enactment of the statute is not established. "It seems to the writer not impossible that the courts will declare that what constitutes waste is a question of fact depending upon the evidence in each case, and not a question of law for declaration by the legislature." ${ }^{34}$ This was written ten years ago, and remains still not finally determined, but with the decisions distinctly tending that way.

The decisions as a whole consequently tend very much to establish that the duty of water is a variable, depending upon what the facts prove to be reasonable in each case, in the discretion of the court.

IV.

With this general premise, a question is presented that is being worked over throughout the irrigation country today, namely, how far older users may be confined to less water when time has changed the duty of water in the same locality. Being a variable, the duty of water is not only different in different localities, but may change in the same locality. Pressure from the increased number of users as settlement advanced has caused later users to insist upon a change to a higher duty of water by the older users than the older users had been enjoying. How far a contmuance of the older methods will be allowed as "beneficial use" is a matter which the decisions of today find increasingly presented for decision.

When the lessened necessity for water is due to physical changes, pretty surely the quantity which the older user may maintam is affected. If seepage from neighboring irrigation raises the ground water level, for example, affording moisture for the land from other sources, the former amount for surface irrigation will not be required per acre. ${ }^{35}$ His older method, resting upon nat-

32 Washington State Sugar Co. v. Goodrich (Idaho, Mar. 3, 1915), 147 Pac. 1073.

33 Hedges v. Riddle (Ore., Feb. 9, 1915), 146 Pac. 99.

34 Water Rights in the Western States, 1st ed., page 333.

35 "After the lower levels are saturated by a few years continuous irrigation such land will require much less water than before and the 
ural conditions before his neighbors came, had only the uncertainties of nature to contend with; restricted to the new conditions he is exposed to the additional hazard of the conduct of his neighbors; if they cease his needs increase again, yet after being once cut down he could not then increase his taking with the same priority as he began. And in conservative times when fear of the future, with its unknown dangers, makes men give primary concern to holding on to what they have and to being protected therein at all hazards-when safeguarding vested rights is observed with nicety-this unsought hazard will be determinative against restricting the older user to such new conditions. ${ }^{36}$ But that is not seriously taken at the present time, which is a time of experimenting and shifting conditions, and in the present temper of the law, it is as though within the maxim de minimis non curat lex. There is more attention given to whether the surplus arising from the lessened necessity may be transferred by him to additional or new land of his own or whether he may sell it. The general ruling has been that he may transfer or sell $\mathrm{it}^{37}$ But the right to change the point of diversion or place or purpose of use of the surplus or to sell it, once strongly recoguized, is more recently losing ground, ${ }^{38}$ and there is a tendency to give the surplus to later appropriators adverse to him. ${ }^{39}$ A representative ruling is: "If conditions change as times pass, and the necessity for the use diminishes, to the extent of the lessened necessity the change inures to the benefit of subsequent appropriators having need of the flow." 40

same quantity of water may then be distributed over a much larger territory." San Joaquin etc. Canal \& Irr. Co. v. Stevinson (1912), 164 Cal. 221, 128 Pac. 924.

${ }^{36}$ See Water Rights in the Western States, 3d ed. $\$ \$, 642,829$, concerning the doctrine "injuria sine damno," whereby one may have protection for the security of his right, although no conditions of actual present damage to him exist, and the protection is against the chance or hazard in the future. See also the present writer's note in 2 Cal. Law Rev. 340.

${ }^{37}$ Ironstone Ditch Co. v. Ashenfelter (1914), 57 Colo. 31, 140 Pac. 177; Groo v. Sights (Wyo., 1913), 134 Pac. 269; Water Rights in the Western States, 3d ed. § 510.

38 See Water Rights in the Western States, 3d ed. $\S \S 496,509$.

39 In re North Powder River (Ore., 1914), 144 Pac. 486. Compare Farmers etc. Canal \& Reservoir Co. v. Wolff (1913), 23 Colo. App 570, 131 Pac. 291; In re Willow Creek (Ore., 1914), 144 Pac. 505; Groo v. Sights (Wyo., 1913), 134 Pac. 270.

40 Conrow v. Huffine (1914), 48 Mont. 437, 138 Pac. 1094, 1096. 


\section{V.}

When the change lessening the necessity for water is due not to physical conditions, but to possible advance in efficiency of methods of employing the water, a much more controverted question is presented. The question assumes that the older user is applying the water efficiently under his original methods, and is not wasting any water viewed from that standard, yet a more efficient method had in time become possible.

That there is some degree to which the introduction of advanced practice may be exacted has been recognized repeatedly of late.41 Of these cases the first and last cited denied the right to complain of a diminution of the head of water in the stream or lake making it impossible to operate the kind of pumps that had been for some time installed there. A method requiring a less head with same efficiency should be installed, it was said. Similarly relief from diversion of underground water supplying a well was denied partly because a change of complainant's arrangements would obviate the damage, ${ }^{42}$ and another case says an independent appropriator having a right to take water from a stream may be required to relinquish his point of diversion from the natural channel, and adopt one from the canal of another person. ${ }^{43}$ In a Nevada case a certain method of use was shown to be wasteful and the court said: "Such a method of diversion would not be an economical use of water providing another reasonable method, under all the circumstances, could be devised to avoid such loss, even though it occasioned some additional expense to the appropriator." 44 In an Idaho case the court intimated that piping or cementing portions of the ditch may be required of him. ${ }^{45}$ In Oregon the court has said that as the demand for water increases, the methods of early settlers must be changed even at considerable expense where more efficiency is possible. ${ }^{46}$

${ }^{41}$ Schodde v. Twin Falls L. \& W. Co. (Idaho, 1908), 161 Fed. 43, affirmed in 224 U. S. 107, 56 L. Ed. 686, 32 Sup. Ct. Rep. 470; Bennett v. Nourse (1912), 22 Idaho, 249, 125 Pac, 1038; Doherty v. Pratt (1912), 34 Nev. 343, 124 Pac. 574; Hough v. Porter (1909), 51 Ore. 318, 98 Pac. 1083, 1102; Donnelly v. Cuhna (1911), 61 Ore. 72, 119 Pac. 331; Little Walla Irr. Union v. Finis Irr. Co. (1912), 62 Ore. 348, 124 Pac. 666; In re Willow Creek (Ore., 1914), 144 Pac. 505; Salt Lake City v. Gardner (1911), 39 Utah 30, 114 Pac. 147.

42 Bower v. Moorman (Idaho, Mar. 23, 1915), 147 Pac. 496.

43 Santa Cruz etc. Co. v. Ramirez (Ariz., 1914), 141 Pac. 120.

44 Doherty v. Pratt, (1912), 34 Nev. 343, 124 Pac. 574.

45 Bennett v. Nourse (1912), 22 Idaho, 249,125 Pac. 1038.

* Hough v. Porter (1909), 51 Ore. 318, 98 Pac. 1083, 1102. In a later Oregon case: "There is no doubt that the methods of irrigation 
These cases recognize that there may be some situations in which the new methods may be imposed against their will upon older users, and they have been interpreted as marking a new unqualified rule of law that such change may always be imposed on older users. In a previous number of this Review, Mr. Frank Adams, presenting resolutions of the Conference of Irrigation Managers of the United States Reclamation Service differentiating "beneficial use" from "economical use," and placing them beside the decisions, shows the tendency both among irrigation managers and courts to declare for "the highest and greatest possible duty." "47 But they are not unqualified. The resolutions declare for a "reasonable" maximum of good with a "reasonably" economical handling of the water, and that the older user adopt every "reasonable" method to reduce the amount of water, and that he make "reasonable" preparation of the ground, and prepare "reasonably" efficient dikes, ditches and structures, and that there be a "reasonable degree" of perfection; they are not unqualified, but continually assert that how far they would go in enforcing innovations is a question of degree, according to what is "reasonable" in each case. And the same qualification as the irrigation managers advocate is recognized in the judicial opinions also. The Supreme Court of Oregon, which at times has been one of the most emphatic in expressions directed to change of method by the older users, also says: "While the crude and wasteful manner of irrigating must be replaced by modern economical methods, yet the ancient means for applying water is not a reason for forfeiting the right to a sufficient amount of water to irrigate the land in a proper manner." ${ }^{38}$ In a California case the matter was directly presented and

in Eastern Oregon have not been so economical as to obtain the best results with the least amount of water, and when conservative methods are adopted it may be found that much less water is necessary than has generally been used. In many cases which have been presented to the courts the testimony has tended to establish, and the courts have allowed, for the average soil, such as loam, clay, or sagebrush land, one inch to the acre. In a few cases where the soil has been gravelly or upon a gravelly subsoil as much as two inches to the acre has been contended for and allowed. This has been based on the testimony as to the need, when used under the ordinary methods then in vogue, in which little attention was paid to systematic or economical application of the water. It is the policy of the law that the best methods should be used and no person allowed more water than is necessary, when properly applied, and thus a larger acreage may be made productive by its extended application." Little Walla Irr. Union v. Finis Irr. Co. (1912), 62 Ore. 348, 124 Pac. 666.

47 The Economical Use of Water, 2 Cal. Law Rev. 367.

48 In re Willow Creek (Ore., 1914), 144 Pac. 505. 
considered and it was held very strongly that continued use of water that could be reduced by better methods gave no right to the excess; but at the same time it was recognized that it was a question of what was "reasonable" in each case; and if the water was actually used the presumption would be that there was no excess, and the burden of proof was on the party contending that the methods should be improved. ${ }^{49}$ In an analogous California case the Court of Appeal held, after much discussion, that the claimant could be made to cement its canal, and the Supreme Court recognizes that this may be so. But it decides that this is a question of fact depending on the circumstances and may or may not be so, and no fixed rule can be laid down. It depends, the court says, upon what is reasonable upon the facts presented in each case. $^{50}$ This qualification runs through most of these decisions.

It has been thought that there is a conflict between these decisions and certain others which recognized the custom of the locality and declined to exact a higher efficiency than custom had generally established. But there is no conflict. The custom of the locality has always been an important factor entering into what is reasonable in each case. In exercising a discretion as to what is reasonable in the case presented, the courts cannot discriminate

49 "In determining how much of the water in fact used had been reasonably necessary for the purpose for which it was used, we believe that a court should be liberal with the appropriator to the extent at least that it should not deprive him of any portion of the amount of water that he had in fact used for the period necessary to gain title by prescription, unless it is clearly and satisfactorily made to appear that he has used more than was reasonably necessary. The presumption would appear to be in his favor, for ordinarily one would not take the pains to use upon any land more than was reasonably necessary under all the circumstances. But we are of the opinion that the findings in this case have designedly been made to present the question of the use by defendant of water not reasonably necessary for the purposes for which it has been used, such a use, as in our view of the law, amounts to waste." California Pastoral etc. Co. v. Madera Canal etc. Co. (1914), 167 Cal. 78, 138 Pac. 718.

50 "There is considerable discussion in the opinion of the district court with respect to the claim of respondent that the plaintiff should be required to cement its canals and to prevent waste by seepage. Its purport on this point is not as clear as could be wished. Inasmuch as the case is remanded for a new trial and these questions are thereupon to be determined by the court below, without a jury, we think all of the discussion on that subject would better have been omitted and we deem it advisable to declare that nothing said about them in the opinion is to be regarded, on the new trial, as the law of the case, and that the court below be left free to decide the case unhampered in this respect. They are questions of fact to be decided in each case upon all the circumstances. No unreasonable expense should be imposed upon the public service company." San Joaquin etc. Canal \& Irr. Co. v. Stevinson (Cal. Mar. 10, 1915), 147 Pac. 258; see also 147 Pac. 254. 
against those who happen to be parties to any suit, leaving the rest of the community to pursue the old methods. Nor would it be supposed that the law ought to take the position that a man, being a member of society, should be required to so use his land as to confer the greatest benefit upon the greatest number of other people without consideration of what is reasonable to himself, and should change his methods of tilling or forfeit his estate to his neighbors. Judge Hawley, whose opinions have held a high place in the law of waters, ruled: "The contention that the prior appropriators of the water ought to be compelled to change their system for the exclusive benefit of subsequent appropriators, who use the same system, does not appeal, in the light of all the facts in this case, very forcibly to a court of equity as being sound." 51 In a recent federal case $^{52}$ a contention by the United States Reclamation Service that such change should measure the existing users' rights so as to permit a subsequent appropriation out of the surplus thereby squeezed out of the older users, likewise failed. ${ }^{53}$ Likewise in Oregon, after full consideration, it was ruled that great expense cannot be demanded of older settlers on small tracts to make them conform to a younger standard of efficiency. ${ }^{54}$

If the method is the customary one in the locality, courts of justice in other connections as well as this have always regarded custom as a specially important factor in determining as a question

51 Rodgers v. Pitt (1904), 129 Fed. 932, 943.

52 United States v. Bennett (Wash., 1913), 207 Fed. 524.

53 "But we know of no law requiring the appropriator of water to change his systen of husbandry to conform with some other system where less water is required. In other words, we know of no law requiring the defendants in this case to cease diverting water for the irrigation of alfalfa or other forage crops heretofore grown on their land and compelling them to reduce their diversion to that required for an orchard or other use requiring less water; nor do we know of any law requiring them to reduce their appropriation of water to the quantity required for a less gravelly and porous soil simply because there is better soil in the neighborhood requiring less water. What is required of the appropriator is that he shall not waste the water appropriated but shall put it to a beneficial use in accordance with the requirements of the husbandry in which he is engaged. In our opinion the decree of the court below conforms to such requirements. The decree is therefore affirmed." United States v. Bennett (Wash., 1913), 207 Fed. 524. See also Nephi Co. v. Vickers (1907), 29 Utah, 315, 81 Pac. 144.

54 "In this case we have a large body of land which has been irrigated almost a lifetime. These older settlers took advantage of the United States statute of 1866 , authorizing settlers to acquire title to the use of water in this manner, and they have secured it, at least to the amount needed and used, and now an effort is being made to reduce the amount to which they supposed their title was perfect. Their methods of use have been those which were the least expensive, and, 
of fact what is reasonable in any case between members of the community. Yet it is not in itself conclusive, nor did these cases say it was; the case is viewed in the light of all the facts, of which custom is but one. These cases were proceeding upon the same line as the others, namely, the court was exercising a discretion as to what was reasonable upon the facts presented. The law has taken a position between either extreme and follows the middle course.

So that how far the older user may, at peril of forfeiture, be forced to keep "up to date" is being recognized as a question of degree, resting in the court's discretion as to what is "reasonable," and a question of fact in each case. He may or may not be forced to do so, according to the particular features of each case, the custom of the locality and the expense of the change being features to be considered with the rest.

VI.

Investigation is developing a scientific "technique" of irrigation. It is demonstrated, for example, that water should be placed six to nine inches below the soil surface and soil mulches of varying thickness should be applied to minimize evaporation losses; fewer and deeper furrows should be used; earlier cultivation should begin, especially in heavier soils, where the percolation is slow and surface moisture content high; cement lining should be put into canals and ditches. ${ }^{55}$ These are but instances of the knowledge being gathered upon the scientific details of irrigation by the experts and investigators.

no doubt, to some extent were extravagant, yet they cannot be expected to install methods now that might reduce to a minimum the amount of water necessary, at a cost that would absorb the profits. A great saving in the amount of water may be possible by adopting the Government Reclamation Service methods (cited as authority here) of cement ditches, to prevent both seepage and evaporation, with experts to follow up and apply the water, by which it is contended that a half inch to the acre is sufficient; but at this time it is to some extent an experiment whether the investment on that basis will be remunerative, at least on the small farms. Furthermore, these government projects are for a new and original use of water, upon which the government can impose such terms as it may see fit. Here the users have acquired the land and applied the water, which are valuable under present conditions, and their rights therein are vested, and we can require them only to use the water economically and reduce the quantity to a minimum by reasonable and cheap methods according to their situation and condition." Little Walla Irr. Union v. Finis Irr. Co. (1912), 62 Ore. 348,124 Pac. 666.

55 ' This demand requires the water user: (a) to make reasonable preparation of the ground surface for irrigation; (b) to use good judg- 
But education in the application thereof must go to the farm before that knowledge can come into court with unqualified authority. As between the rule, above indicated to be the law, leaving the degree of improvement to what the court, from all the facts in proof, finds a reasonable requirement in each case, and another (which, as also above indicated, no one advocates) exacting the highest possible efficiency known to science in all cases, it is easy to see which would survive in the struggle for law.

It still seems true, therefore, of "beneficial use," as a rule of present law, that "the question is one of fact, a very general one, depending upon the attitude which the jury (or judge) as reasonable men, will take toward the evidence as a whole." And from the decisions of the last four years it appears that the question of fact is whether the use is a reasonable use between the parties under the circumstances in each case according to the court's best idea of fairness to all. The transmission allowance appears as whatever is proved reasonable in degree; the duty of water at the land is whatever the facts prove to be reasonably required; whether change to a higher duty must be made depends in each case upon whether it can be reasonably done with fairness to all parties; and together these factors determine the ultinate fact of "beneficial use." The discretion of the court remains the increasingly important element, determining what is "reasonable" in each case according to the facts proved, subject to appeal in case of clear abuse of discretion. The law requires that degree of efficiency by the appropriator which the court, after hearing all sides and seeking to be fair to him not less than to the other parties, believes it is reasonable to require of him.

It is evident that a tendency, so active elsewhere in the law, is coming to be reflected here also. Another instance was considered by the present writer in reference to decisions which decline to give full effect to any priority that is considered "un-

ment in selecting appropriate methods of applying the water to the ground; (c) to prepare reasonably efficient dikes, ditches and structures to get the water over the land in such a way as to reduce the underground losses to a minimum; (d) to irrigate with such a head and at such intervals as to require a minimum use of water for proper irrigation; and (e) to cultivate the irrigated ground when practicable to prevent undue losses from evaporation; in some cases possibly to govern the character of crops to be grown." Resolution 67 of the Conference of Irrigation Managers of the U. S. Reclamation Service, quoted in $2 \mathrm{Cal}$. Law Rev. 373. 
reasonable," resort to reasonableness in determining the allowances and restrictions surrounding "beneficial use" has been pointed out by another in a previous number of this Review. ${ }^{57}$ As this discretionary feature increases, the test between appropriators is becoming increasingly like the test at common law between riparian owners; namely "reasonable use," which means that consumption of the water between the members of either class among themselves is subject to the power of the court to apply its ideas of fairness in each case. The idea of a definitely fixed segregation of quantity for each appropriator unvarying forever is not holding its own, and the amount of water he may have becomes subject to variation from time to time according to variation in the conditions that surround him (as it likewise varies between riparian owners at common law), and subject to the fairness of the court (as opposed to fixed rule) apportioning the use between the parties.

"Reasonableness" as a test lies in many districts of the law. There is the level valley where "reasonable care" governs the law of negligence and "reasonable time" plays a large part in the law of contracts; from there we pass to the foothills where "reasonableness" of rates and service governs the law of public service companies; some stations on we reach the snow-line where "reasonable restraint of trade" ("light of reason") agitates the law of trusts and monopolies. All these but mean that it is a question of degree, resting upon the discretion of the authority that is to decide. And discretion carried to the end becomes personal government, and we get off at the very summit where we fight for a government of laws and not of men.

But the "beneficial use" matter does not yet take us out of the placid valley, and let us hope that it will learn to stay there.

San Francisco, California.

Samuel C. Wiel.

56 Water Rights in the Western States, 3d ed. $\S 310 ; 18$ Yale Law Journal 189; 27 Harv. Law Rev. 530. Rev. 367 . 